\title{
المناسبات في فواتح سورة مريم من خلال تفسير الرازي(ت606هـ)$$
\text { - جمعًا ودراسة وموازنة - }
$$$$
\text { أحمد عبدالكريم الكبيسي } 1 \text { ، صفاء فيصل الصديق احمد } 2
$$

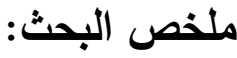

يهذف البحث إلى التعريف بماهية المناسبات، وذكر قسميها: الخارجية، والداخلية،

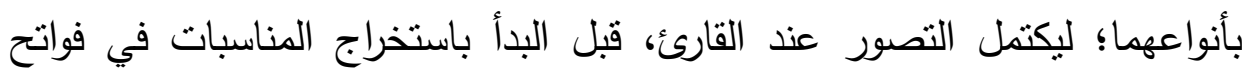
سورة مريم 1-6 من خلال تفسير الرازي مقارنة بتفسير ابن عانشور رحمها

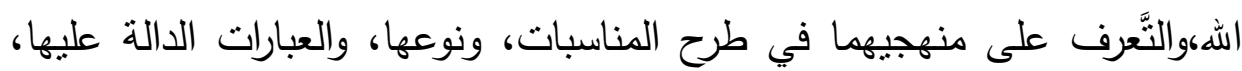

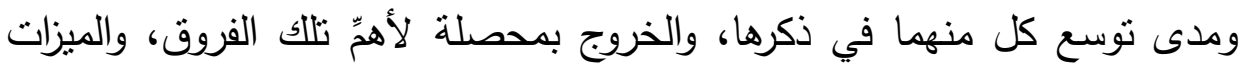

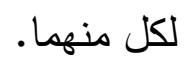

ولعلَّ هذا ما يُساعد القارئ الكريم في الوصول إلى المناسبات الواردة في تقسيريهما، ومراد اختباريهما ومن الله التوفيق والسيَّاد. الكلمات المفتاحية: المناسبات، الزازي، ابن عاشتور.

\section{Abstract}

This research aims to define what is occasions, and presenting two divisions: external and internal, and their types; to complete the visualization for the reader, initially, we start to extract the occasions in permissible in Surat Maryam 1-6 from El Razi commentary with comparison with Ibn Ashour commentary may their souls rest in peace, and identifying their methods in positing occasions, and their types, and function statement, and extent of expansion with mentioning both of them, and coming with outcomes for more important distinguishing, and the advantages of both.

However, may this help the kind reader to reach the occasions received in both commentaries, and the studies behind the choosing of the topic and from god the good luck and the rectitude.

Key words: occasions, El Razi, Ibn Ashour. 
إنَّ الحمد لله، نحمده ونستعينه ونستغفره ونعوذ باله من شرورأنفسنا، ومن سيئات

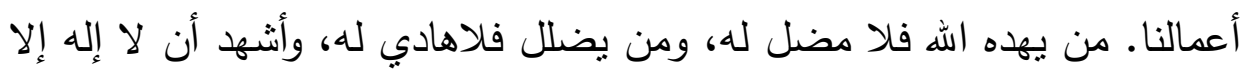
الله وحده لاشريك له، وأشهة أن محمداً عبده ورسوله.

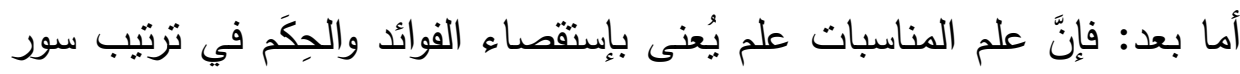

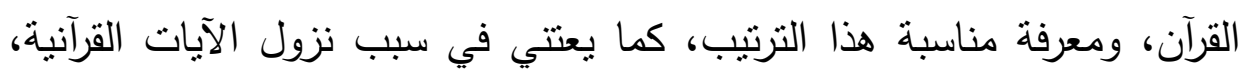

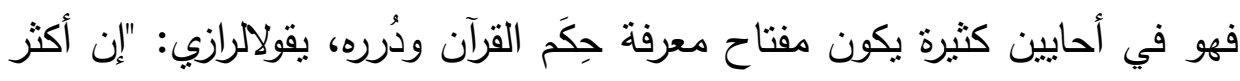

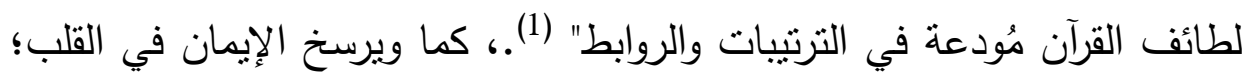

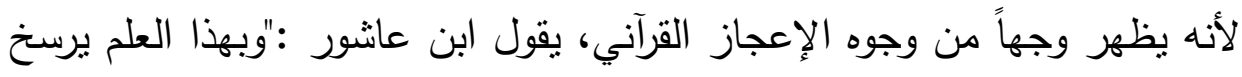

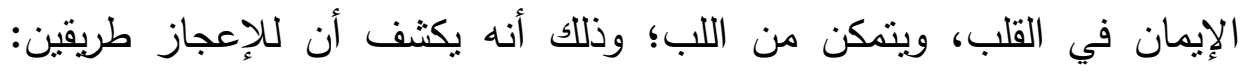

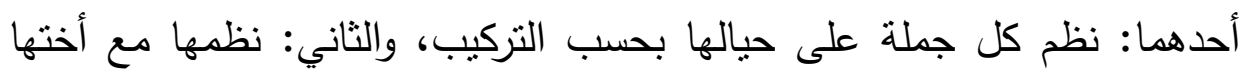

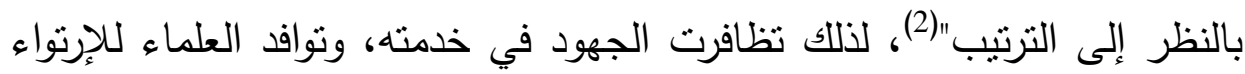

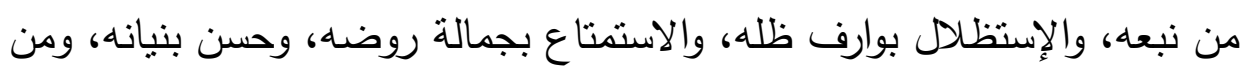

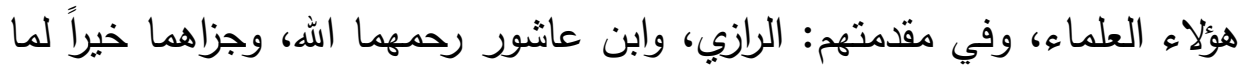
أثريا هذا العلم، وأبرزاه بكل جدارة. حدودالبحث: تقديم نموذج هامومبسط،عن علم المناسبات القرآنية، من خلال تقسير

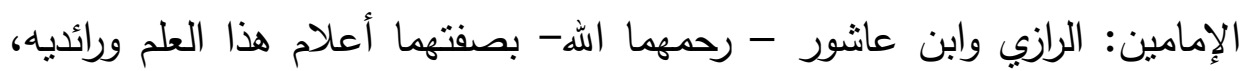

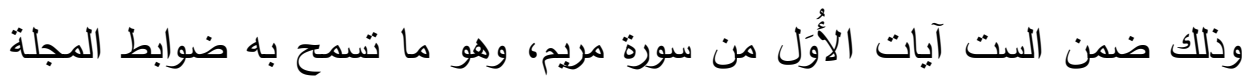
حول عدد أوراق البحث.

(1)الرازي، محمد بن عمر بن الحسن بن الحسين التيمي ، مفاتيح الغيب ، (بيروث: دار إحياء

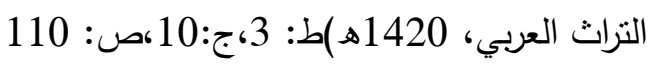

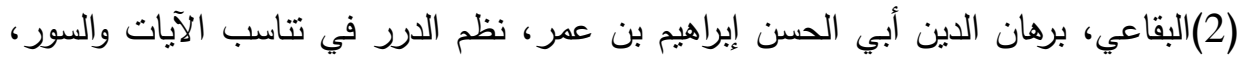

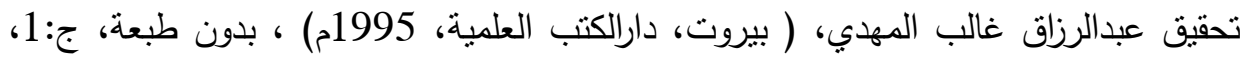
ص:6. n n 
إثكالية البحث:

- هل ذكر الإمامان: الرازي، وابن عاشور، مناسبات في فواتح سورة دريم، وماأنواعها؟ -مامدى عناية الإمامين بالمناسبات، من خلال الست آيات الأُؤل من سورقدريم ؟ - ما هي أهم الفروقات في منهج الإمامينحول المناسبات ؟ أهداف البحث - جمع ماذكره الإمامين في فواتح سورة مريم، من مناسبات، وبيان أنوعها. - بيان مامدى عناية الإمامين بالمناسبات، من خلال فواتح سورة مريم. - معرفة أهم الفروقات في منهج الإمامين، فيما يخص المناسبات.

\section{الاراساتالسابقة : معرست}

إن دراسة علم المناسبات بين الآيات والسور القرآنية ليست دراسة جديدة حيث اعتنى بها عدد من الباحثين قديماً وحديثاً، ومن ذلك مثلاً: > آيدين: محمد مصطفى، "المناسبات بين الأسماء الحسنى والآيات التي ختمت بها"، وهذا البحث يختلف عنه بالجانب التطبيقي لسورة مريم بكل مافيها. القرني، عبداله بن مقبل بن ظافر (1992م)، وعنوانها:(المناسبات في القرآن الكريم ودراسة تطبيقية في سورتي الفاتحة والبقرة من تقسير الفخر الرازي)، وكانت عبارة عن رسالة ماجستير في جامعة أم القرى بمكة المكرمة، تتاول فيها الباحث التعريف بعلم المناسبات، وقواعده وضوابطه، وفوائده، وتاريخه، وأشهر المهتمين به، ثم نبذة عن حياة الرازي وكتابه مفاتيح الغيب، ثم دراسة مناسبات سورة الفاتحة والبقرة 


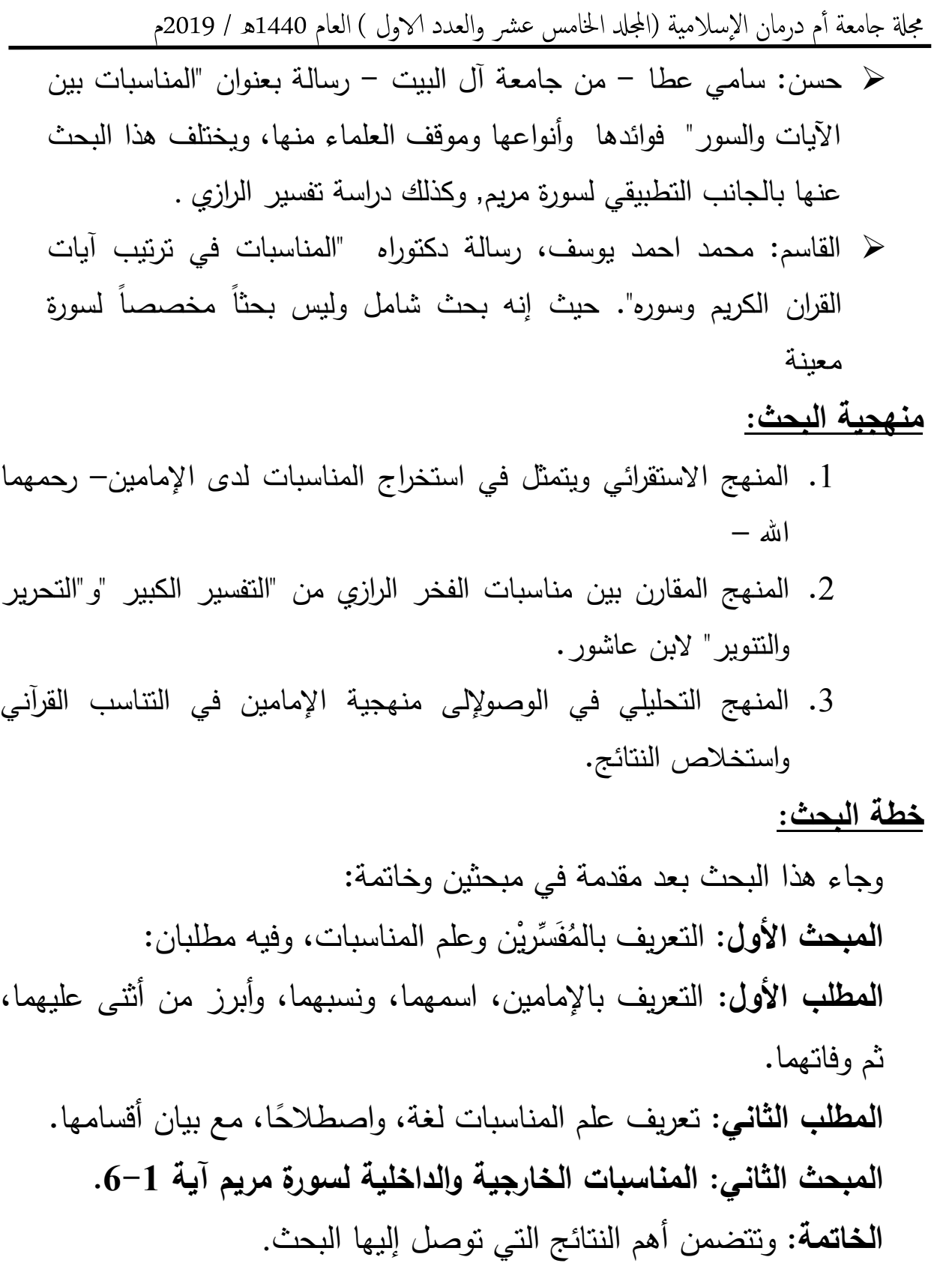


المناسبات في فواتح سورة مريم من خلال تفسير الرازي - دـ أمد عبدالكريم الكبيسي وصفاء فيصل الصديق

\section{المبحث الأول \\ التعريف بالمُفَسِّرِيْن وعلم المناسبات}

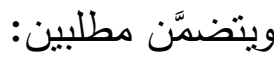

المطلب الأول: التعريف بالإمامين- موجزًا-

أولاً:الرازي:

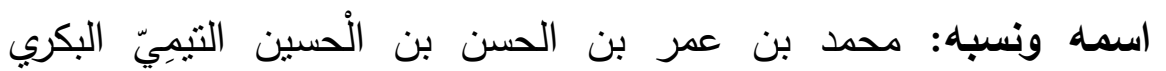

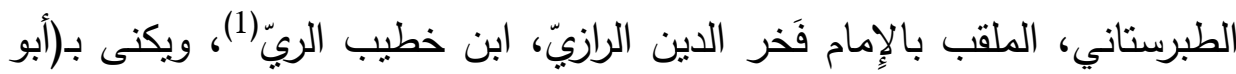

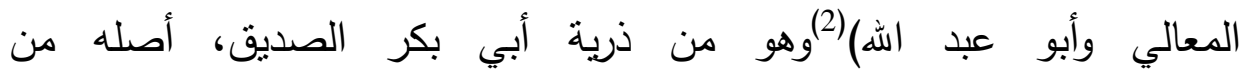
طبرستان، (3) ولد في الري، (4) إليها نسبته (5).

(1) السبكي، تاج الدين عبد الوهاب بن تقي الدين، طبقات الثافعية الكبرى، تحقيق: محمود محمد

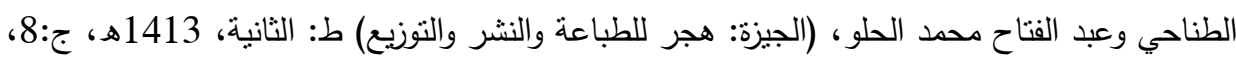
ص: 81 (n) ابن كثير، إسماعيل بن عمر ، طبقات الثافعيين، تحقيق:أحمد عمر هاشم، محمد زينهم محمد عزب،

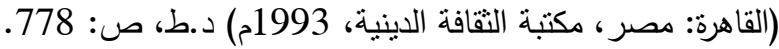
(2)(بن كثير ، إسماعيل بن عمر القرشي ،البداية والنهاية، (بيروت، دار الفكر، 1986 م)، د.ط، جانه: 13، ص:5. (3) طبرستان بفتح أوله وثانيه وكسرالراء، هي بين الري وقومس والبحر وبلاد الديلم والجيل وهي كثثرة

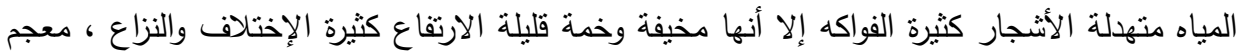

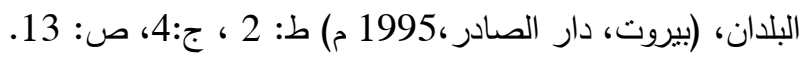
وكان اسم طبرستان: يطلق في القرون الولى للهجرة على جميع الجهات الساحلية والجبلية الواقعتشترقي نهر هراز وغربيه، ولكن منذ القرنالسابع للهجرة اخذ اسم مازندران يقضي على اسم طبرستان حتى بطل

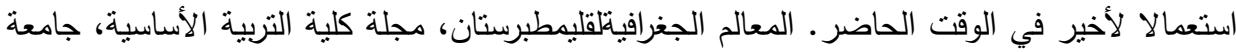

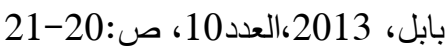
(4) الري: مدينة مشهورة من امهات البلاد واعلام الددن كثيرة الفواكه و والخيرات،هي اليوم مدينة صغيرة مهجورة قريبة من مدينة طهران عاصمة إيران. الحموي، معجم البلدان(116/3) (5) عادل نويهض، معجم المفسرين من صدر الإسلام وحتى العصر الحاضر ، تحقيق: الثنَّنَخ حسن خالد، (بيروت، مؤسسة نويهض الثقافية للتأليف والترجمة والنشر ، 1988 م) طا: 3 ، 3

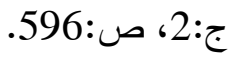


مجلة جامعة أم درمان الإسلامية (الججلد الخامس عشر والعدد الاول ) العام 1440هـ / 2019م

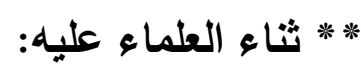

احتل الرازي المنزلة الرفيعة والمكانة العالية، ونال تقدير واحترام المجتمع على اختلاف طبقاته، فبالغ في احترامه العلماء وطلاب العلم، والسلاطين، وخاصة الناس وعامتهم. وتواترت أقوال العلماء والمؤرخين الذين وصفوه بأحسن الكلام ورفعوه إلى أسمى المراتب، التي تدل على أنه حظي بمكانة عظيمة بين العلماء لم ينلها عالم آخر في عصره، وأبلغ من أنتى عليه، السبكي قائلا: إمام المتكلمين، ذو الباع الواسع في تعليق العلوم، والاجتماع بالثاسع من حقائق المنطوق، والمفهوم، والارتفاع قدرا على الرفاق، بحر ليس للبحر ما عنده من الجواهر، وحبر سما على

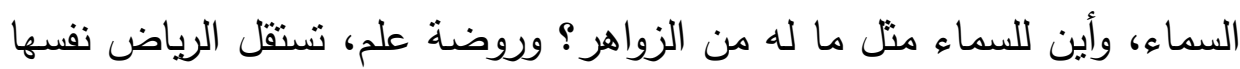
أن تحاكي ما لديه من الأزاهر • انتظمت بقدره العظيم عقود الملة الإسلامية، وترفع، فلم يرض إلا بنكت، تسحر ببيونها، وأتى بجنات طلعها هضيم، وكلمات

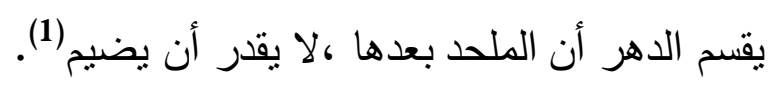
وفاته:

توفي ببلدة هراة(2) وأملى في شدة مرضه وصية على تلمبذه إبراهيم بن أبي بكر بن علي الأصفهاني وذلك في يوم الأحد الحادي والعشرين من شهر المحرم سنة ست وستمائة، وامتد مرضه إلى أن توفي يوم العيد غرة شوال من السنة المذكورة وانتقل

(1) السبكي ، طبقات الثافعية الكبرى (81/82-82)

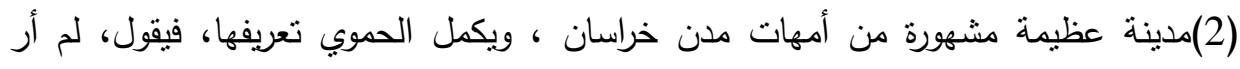
بخراسان عند كوني بها في سنة 670 مدينة أجل ولا أعظم ولا أفخم ولا أحسن ولا أكثر أهلا

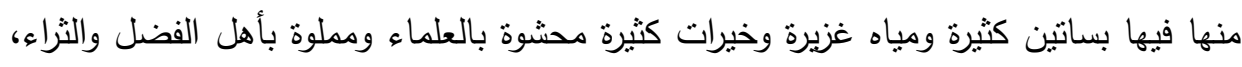
معجم البلدان ، (5/ 396 ) بتصنين 
إلى جوار ربه رحمه الهه تعالى (1)، وقيل إنَّ الكرامية توصلوا إلَّى إطعامه السم فئل (2) ثانيًا:إين عاشيور:

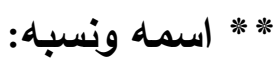

محمد الطاهر بن محمد الثاذلي بن عبد القادر بن محمد بن عاشور، نقيب

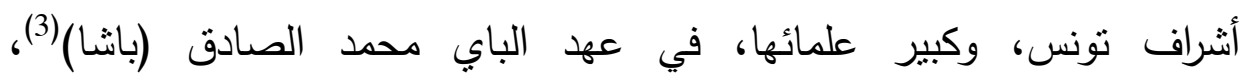

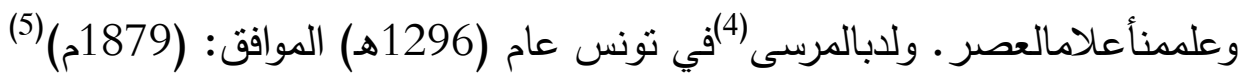

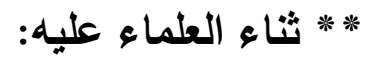

لقد صطع شمس ذلك العالم الجليل، حتى عمت شمس علمه جل الأمصار ، فيقول

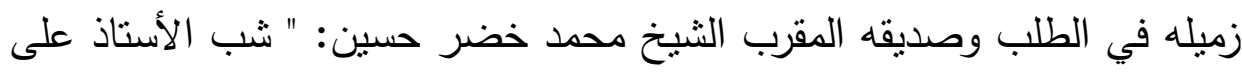
ذكاء فائق، وألمعية وقادة، فلم يلب أن ظهر نبوغه بين أهل العلم، وله فصاحة منطق، وبراعة بيان، بالإضافة إلى غزارة العلم، وقوة النظر، وصفاء الذوق، وسعة النهاء

(1)ابن أبي أصييعة، أحمد بن القاسم بن خليفة بن يونس،عيون الأنباء في طبقات الأطباء،

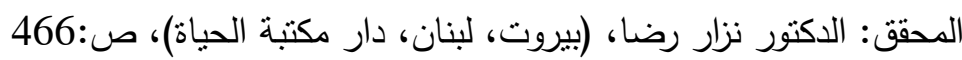

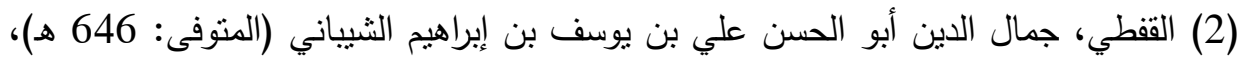

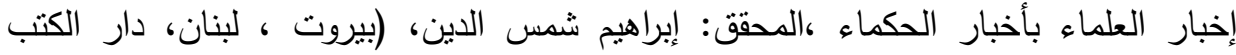
العلية، 2005م) ط:1، ص:220 (3) الزركلي، خير الدين بن محمود بن محمد بن علي،الأعلام (بيروت،لبنان، دار العلم للملايين 2002)

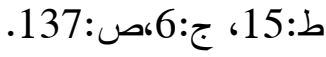
(4)ضاحية جميلة من الضواحي الثمالية للعاصمة التونسية، تقع على شاطئ البحر المتوسط،

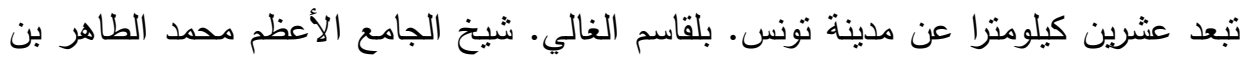

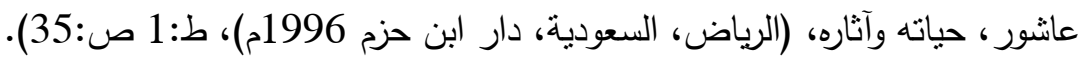

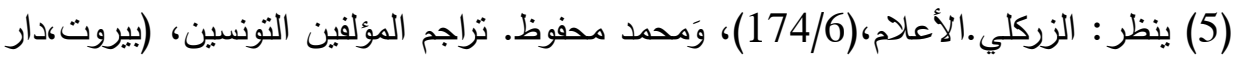

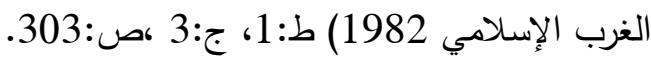




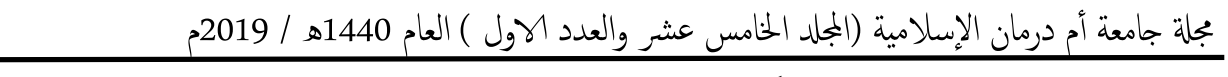

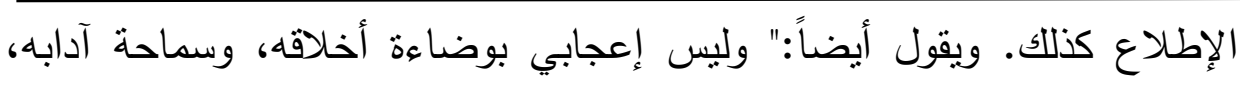
بأقل من إعجابي بعبقريته في العلم" (1).

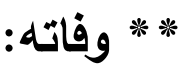

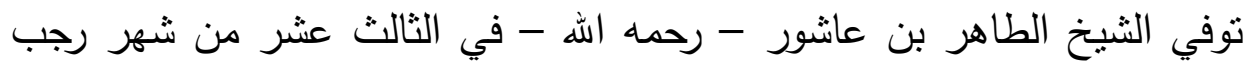
سنة (1393هـ) الموافق الثاني عشر من شهر أغسطس سنة 1973م، وكان وكان عمره آنذاك 97 سنة، وذلك بعد أن عاش- يرحمه اله - حياة حافلة بالعلم والتجديد

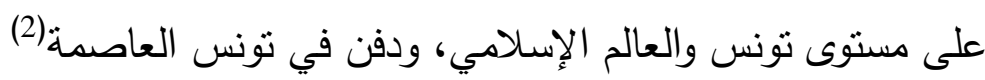
المطلب الثاني: التعريف بالمناسبة، وأنواعها تعريفها لغة:لها تعاريف لغوية كثيرة، لكن من أهمها ماذكر في معجم مقاييس

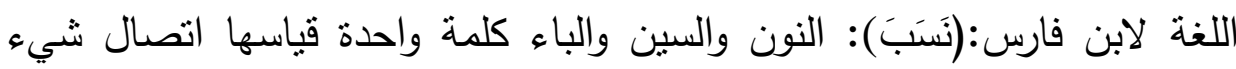
بشيء. منه النسب، وللاتصاليه نقول: نسبت أنسب. وهو نسيب فلان. ومنه النسيب في الثعر إلى المرأة، كأنه ذكر يتصل بها؛ ولايكون إلا في النساء. نقول

منه: نسبت أنسب. والنسيب: الطريق المستقيم، لاتصال بعضه من بعض(3).

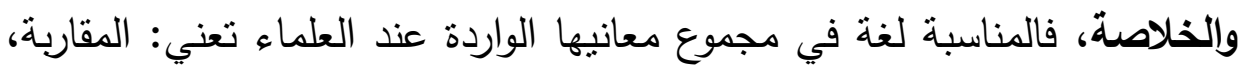

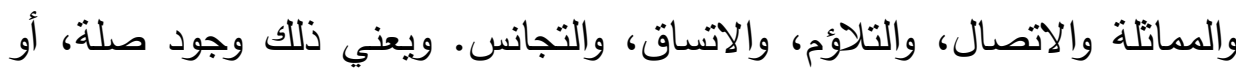
اربط يقارب بين شيئين في نسق واحد واتصال معقول يظهر وجه النظم بين السور

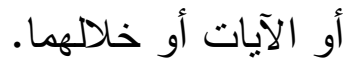

(1)محمد خضر حسين، تونس وجامع الزيتونة، تحقيق: علي الرضا،( المطبعة التعاونية 1391هـ)، ط:1،صنر:124 (12)

(2) ينظر : الزركلي،الأعلام، (164/6)، محمد محفوظ. تراجم المؤلفين التونسيين، (307/3).

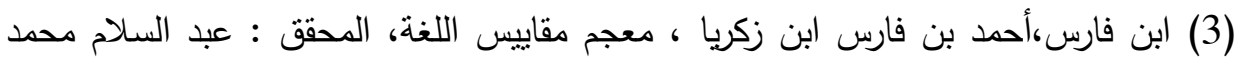

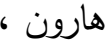
( (بيروت:دار الفكر، 1979 م) ، ج:5، ص:423. 
اصطلاحاً:"علم تعرف منه علل ترتيب أجزائه - القرآن- وهو سر البلاغة لأدائه

إلى تحقيق مطابقة المعاني لما اقتضاه الحال".(1)

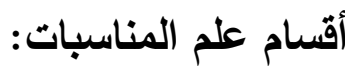

القسم الأول:المناسبات بين السور، وتسمى أيضا المناسبات الخارجية، ولها ثلاث صور:

1. مناسبة مطلع السورة مع مطلع ما قبلها.

2.مناسبة مطلع السورة مع خاتمة ماقبلها.

3. مناسبة مقاصد السورة مع مقاصد التي قبلها.

القسم الأول: المناسبات في السورة الواحدة، وتسمى أيضاً المناسبات الداخلية. ولها خمس صور :

1. المناسبات بين الجمل في الآيةالواحدة. 2.المناسبة في ترتيب الآيات.

3.مناسبة مطلع السورة مع مقاصدها. 4.مناسبة خاتمة السورة مع مقاصدها.

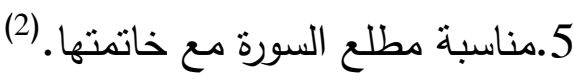

(1) البقاعي، برهان الدين أبي الحسن إبراهيم بن عمر، نظم الدرر في تناسب الآيات والسور ، البهان

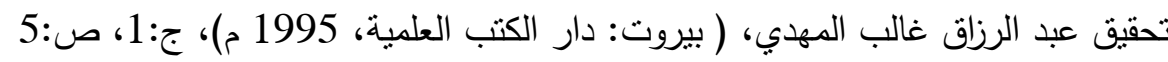
(2)محمد بن عمر بن سالمبازمول، علم المناسبات في السور والآيات، (السعودية :مكتبة مكة،

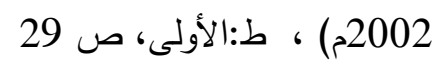




\section{المبحث الثاني}

المناسبات الخارجية والاخلية لسورة مريم آية 1-6

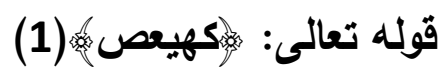

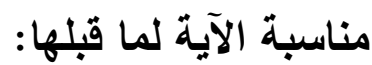

الرازي

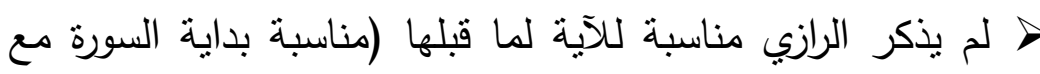

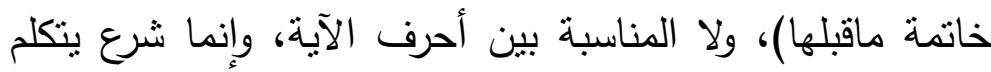

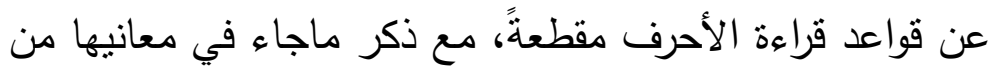

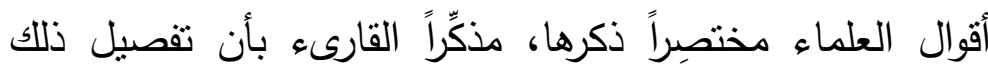
مذكورٌ في تفسير سورة البقرة (1).

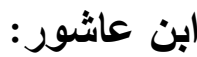

> سلك مسلك الرازي في مايخص الأحرف المتقطعة في تفسير

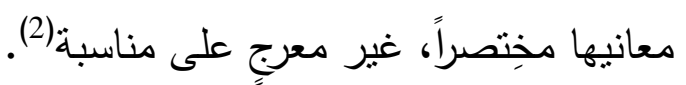

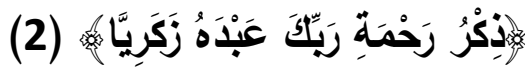

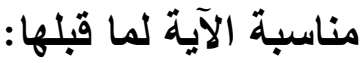

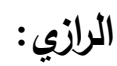

> استفاض رحمه الله في ذكر القراءات الواردة في هذه الآية

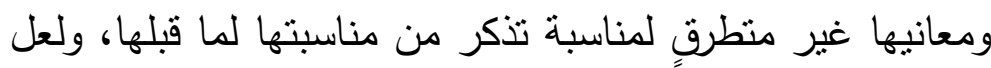

$$
\text { (1) أنظر : مفاتيح الغيب، (21 /506-505.) }
$$

(2) انظر : ابن عانور ، محمد الطاهر بن محمد بن محمد، التحرير والتتوير ، ( تونس، الدار

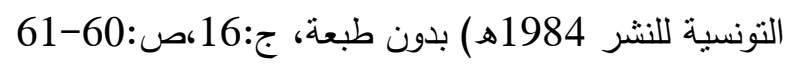


ذلك لترجيحه أن معاني تلك الأحرف مما استأثز الله تعالى بعلمه،

$$
\text { فكيف بربط بما لم يُعرف دعناه! }
$$

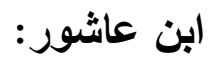

ومثل ما فعل الإمام الرازي، فعل الإمام ابن عاشور في عدم ذكر

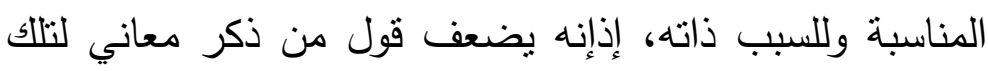

الأحرف، فإذا ذكر مناسبة، فيكون ذلك بحكم الناقض للتضعيف.

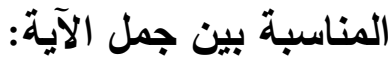

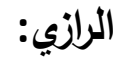

لم يذكر الرازي مناسبة واضحة بين جمل هذه الآية كما

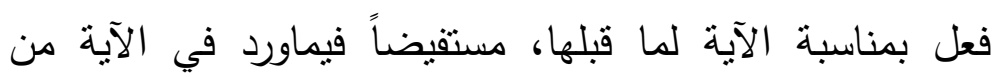

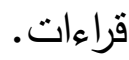

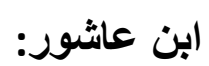

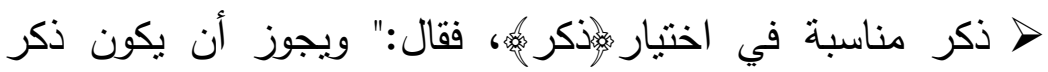

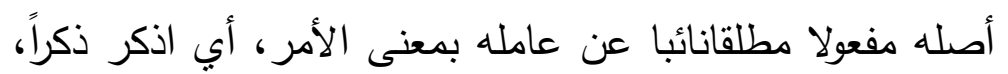

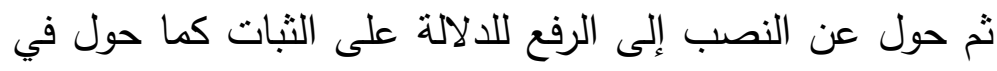

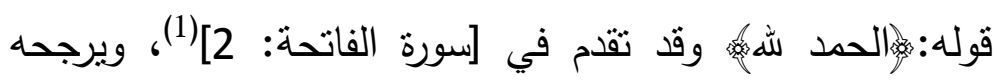

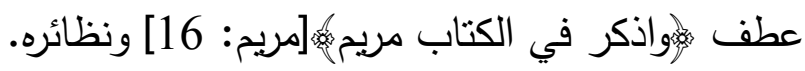
> ولعلنا نستقيد من معنى كلامه - رحمه اله - بتعليل الإتيان

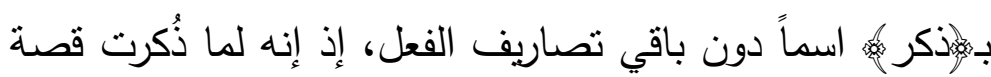

(1)"العدول عن النصب هنا إلى الرفع لينأتى لهم الدلالة على الدوام والثبات بمصير الجملة

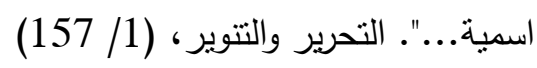




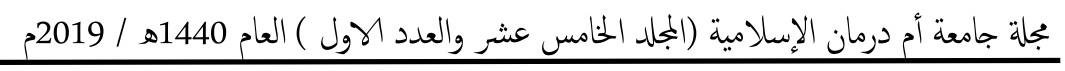

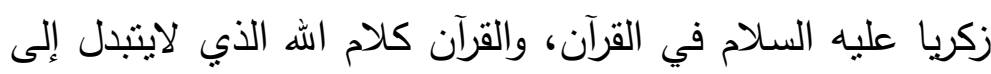

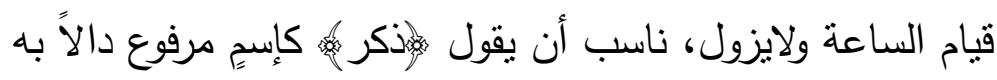
على الثبات والاستمرار لهذا الذكر والانتفاع به.

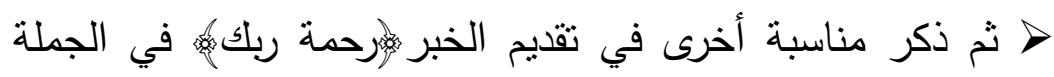

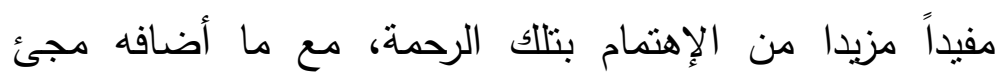

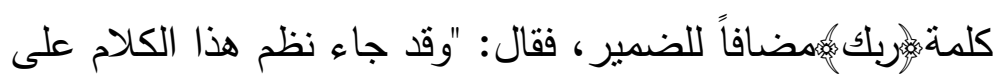

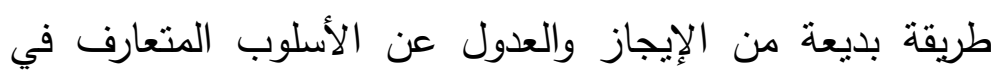

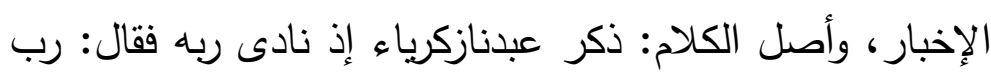
.إلخ، فرحمة ربك، فكان في تقديم الخبر بأن الله رحمه اهتمام

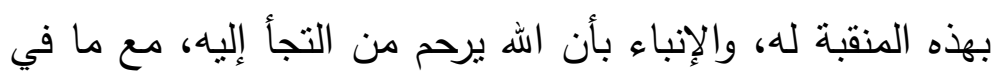

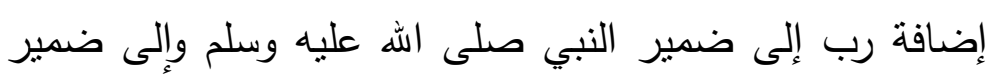
زكرياء من التتويه بهما"(1).

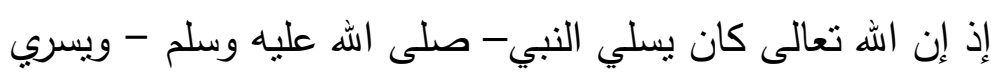

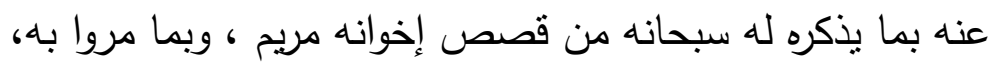

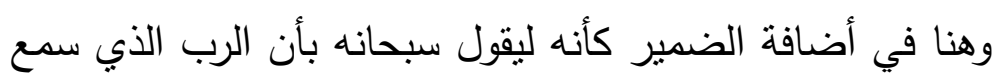
مناجاة عبده الضعيف زكريا، هو نفسه ربك الذي يسمع دعائك لئك

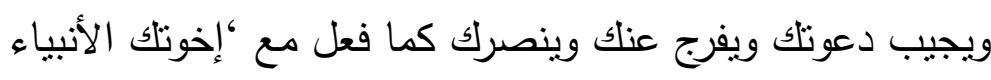
من قبلك.

(16) (162 (16) ، التحرير والتتوير 


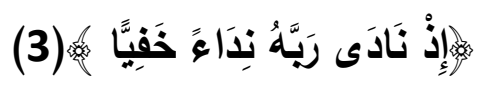

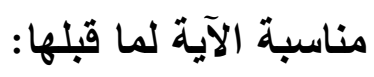

الرازي:

> لم يذكر الرازي، ولا ابن عاشور مناسبة للآية لما قبلها، لكن

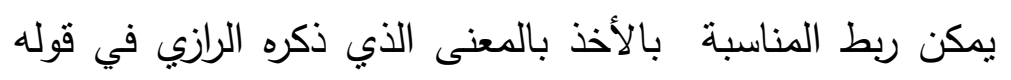

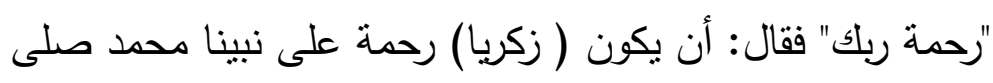

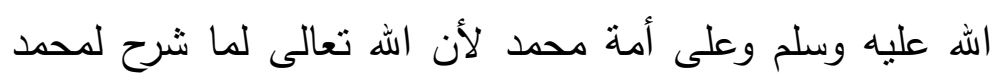

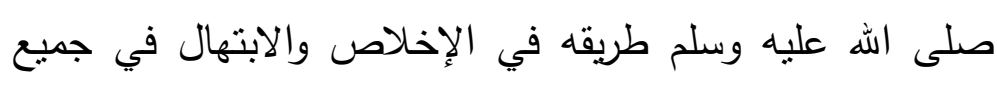

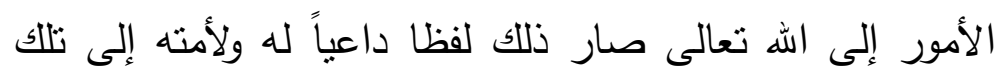

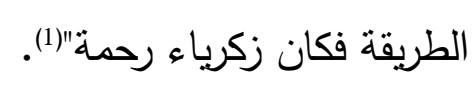

أي أن اله شرح تلك الرحمة التي كانت نكرة في الآية الثانية،

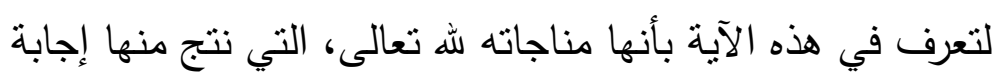

$$
\text { الدعاء. }
$$

المناسبة بين جمل الآية الواحدة: - الماه

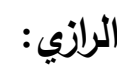

خ ذكر مناسبة ذكر" خفياً" مع النداء،قائلاً: " راعى (زكريا) سنة الله

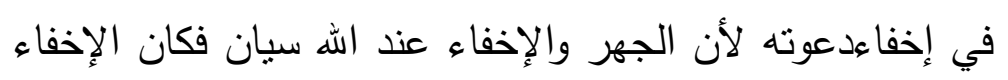
أولى لأنه أبعد عن الرياء وأدخل في الإخلاص. والإنهاء لإنيها: أخفاه

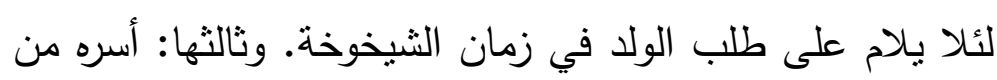

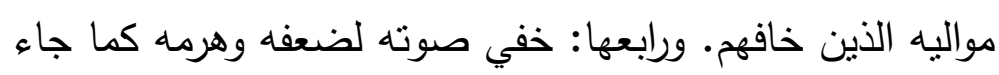

في صفة الثيخ" (2) فولهن

(1)مفاتيح الغيب ، (21/ 507)

(2)مفاتيح الغيب، (21/ 507) (5ناني ) 
مجلة جامعة أم درمان الإنسلامية (الجلد المامس عشر والعدد الاول ) العام 1440هـ / 2019م

وابن عاشور:

كالرازي في هذا الموضع إذ قال:" وإنما كان خفياً:لأنَّ زكرياء رأى أنى أنه أدخل في الإخلاص مع رجائه أن الله يجيب دعوته لئلا نكان النكون استجابته مما يتحدث به الناس "(1).

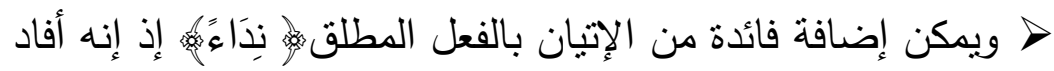

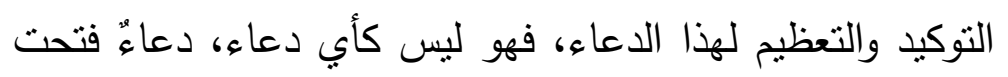

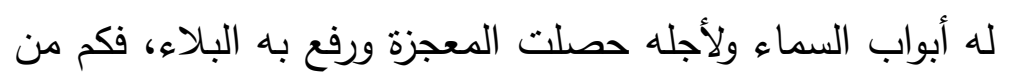

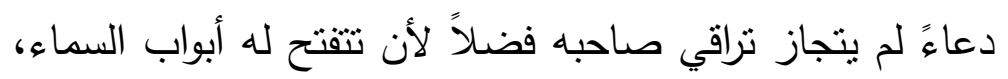

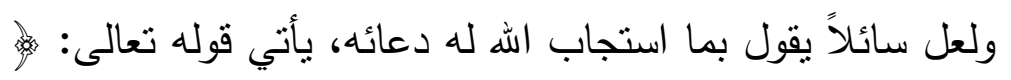
خَفِيَّ

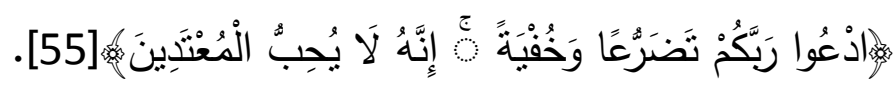
> ولعلّ ذلك - واله أعلم- من أسباب تفضيل الدعاء في الثلث الأخير

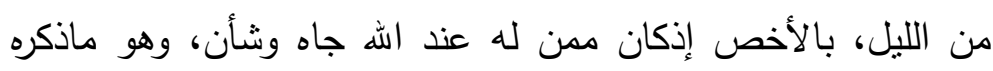

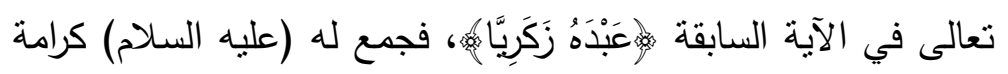

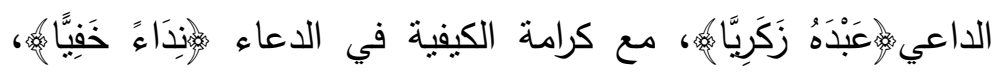

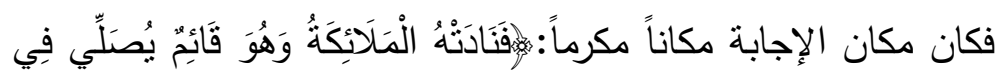

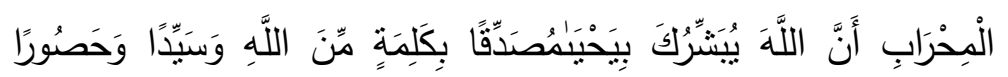

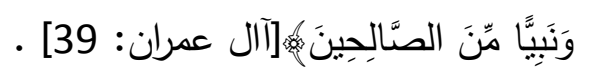

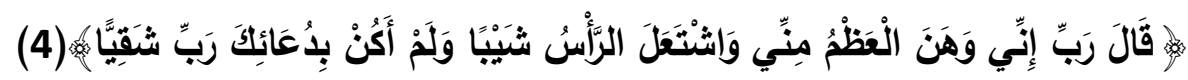

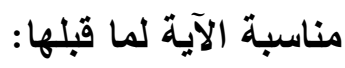

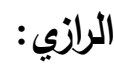
> لم يذكر الرازي مناسبة للآية مع ما قبلها.

(1) (16) ، (16) (التحرير والتتوير 


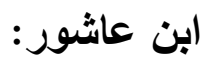

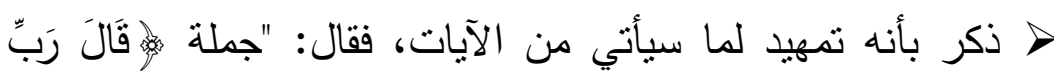

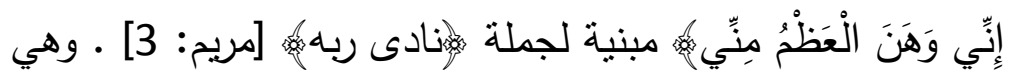

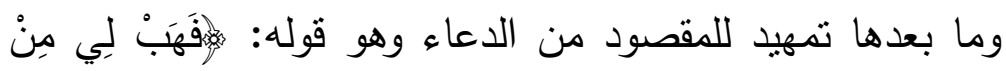

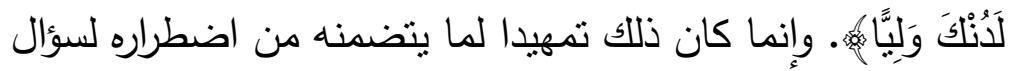
الولد. واله يجيب المضطر إذا دعاه، فليس سؤاله الولد سؤال

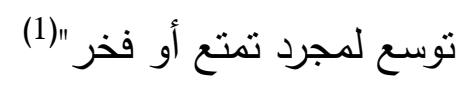

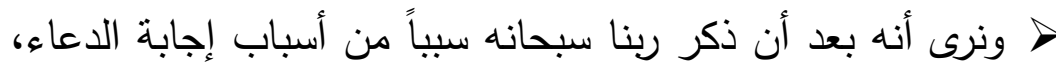

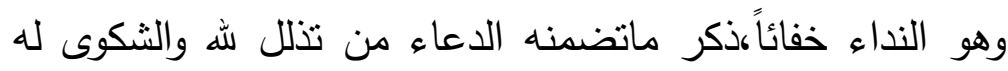

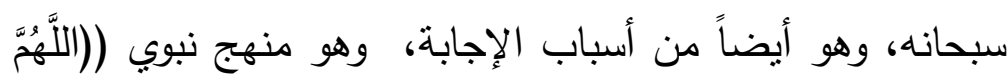

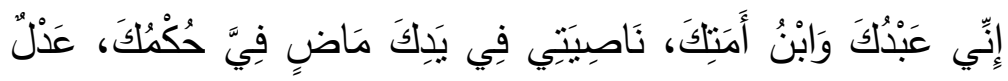

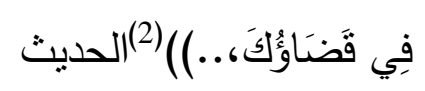

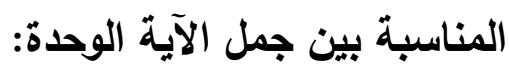

الرازي

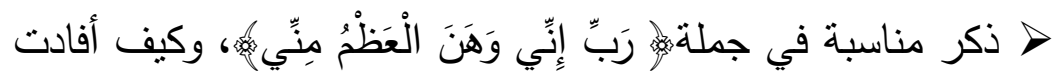

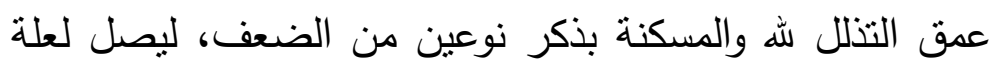

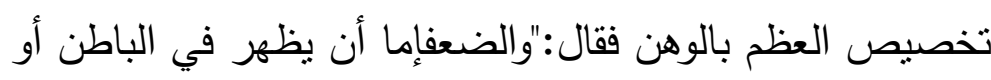

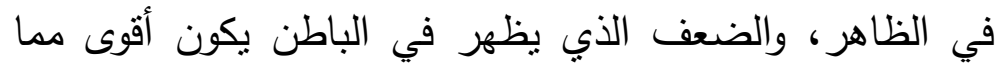

$$
\text { (1)(التحرير والتتوير، ( } 16 \text { (16/) }
$$

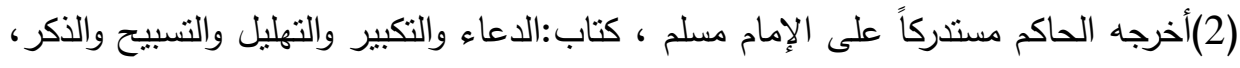

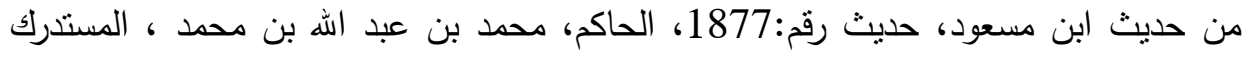

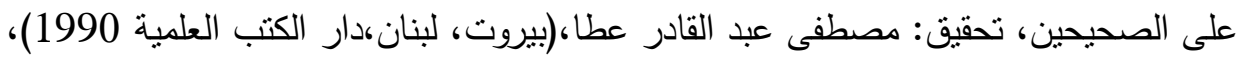

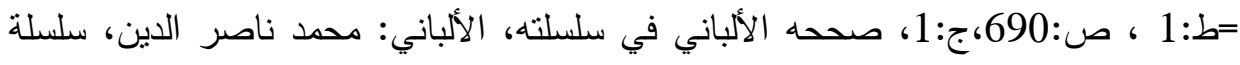
الأحاديث الصحيحة، (الرياض، السعودية، مكتبة المعارف:1990م)، ط:11، ج: 1، ص:383. 
مجلة جامعة أم درمان الإسلامية (المجلد الخامس عشر والعدد الهول ) العام 1440هـ / 2019م

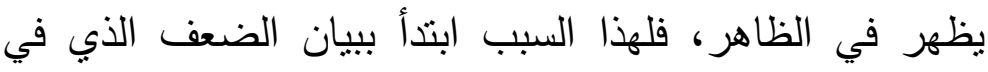

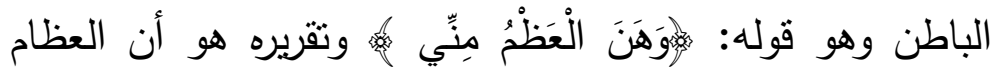
أصلب الأعضاء التي في البدن وجعلت كذلك لمنفعتين: إحداهما:

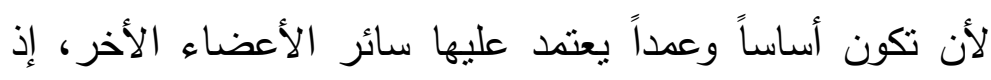

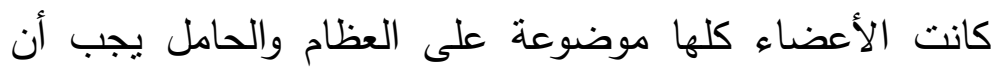

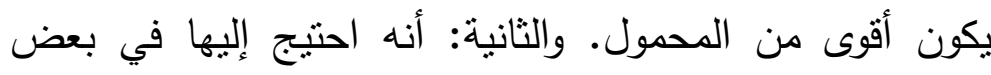

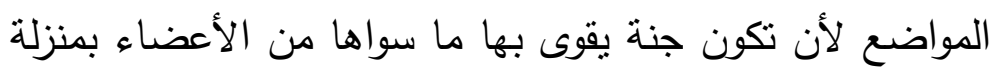

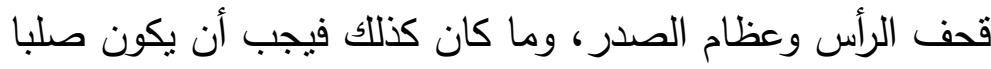

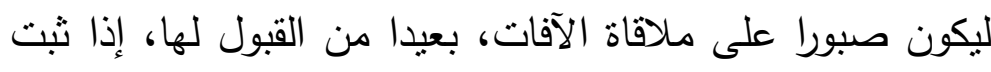

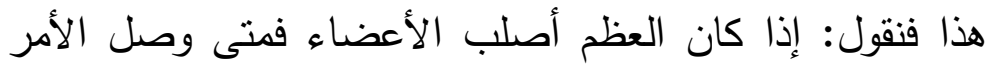

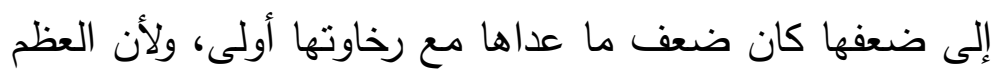

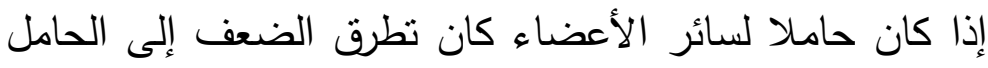

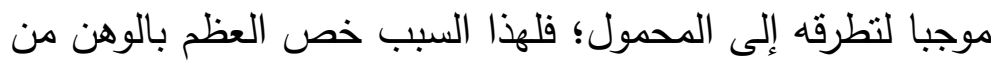
بين سائر الأعضاء وأما أثر الضعف في الظاهر فلاهلك الستيلاء

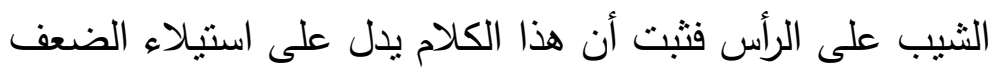

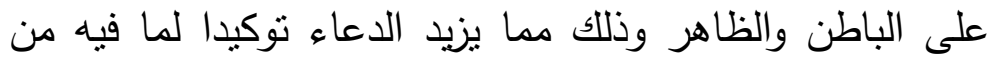
الارتكان على حول الله وقوته والتبري عن الأسباب الظاهرة" (1)

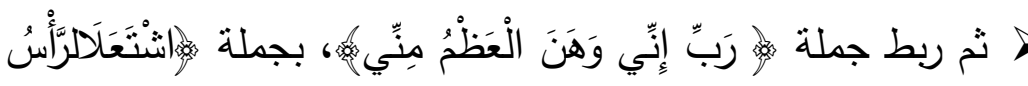

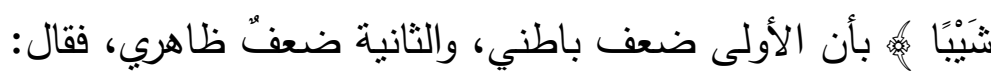

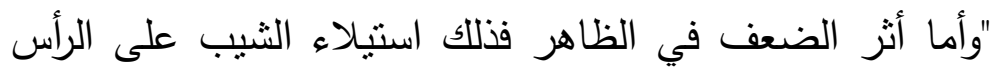
فتبت أن هذا الكلام يدل على استيلاء الضعف على الضى الباطن

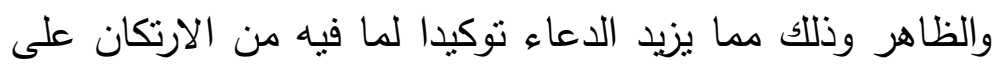

(1)مفاتيح الغيب، (21/ 509) 
حول الله وقوته والتبري عن الأسباب الظاهرة"(1)

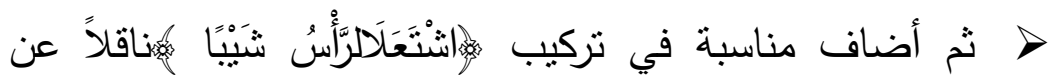
صاحب الكثاف قوله: " شبه الثيب بشواظ النار في بياضد

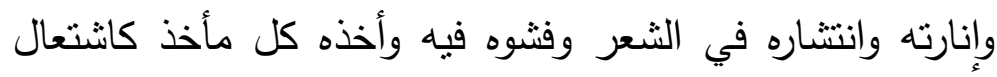

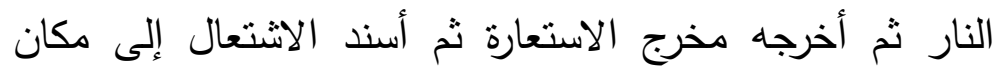

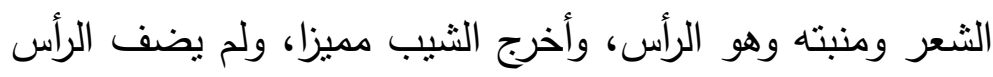

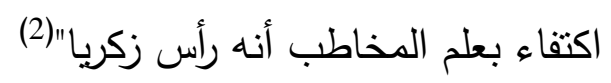

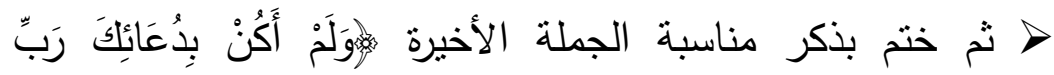

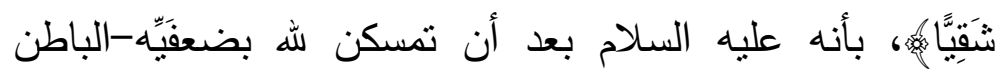

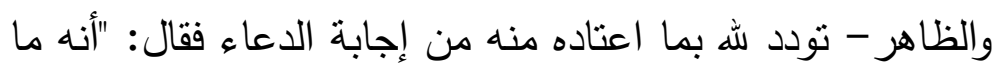
كان مردود الدعاء البتة ووجه التوسل به من وجهين:

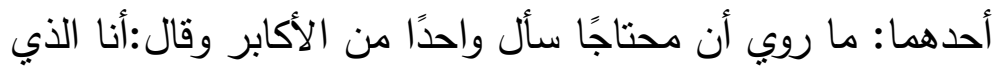

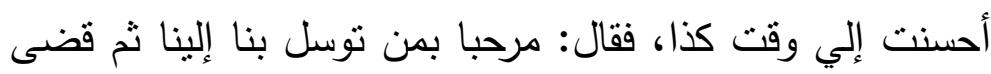

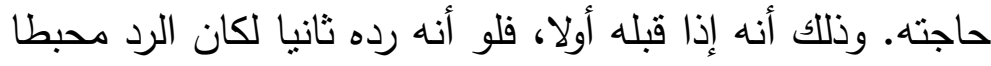
للإنعام الأول والمنعم لا يسعى في إحباط إنعامه.

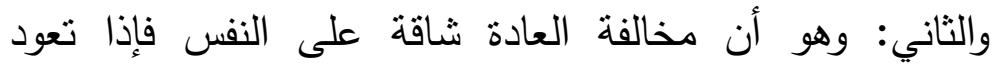

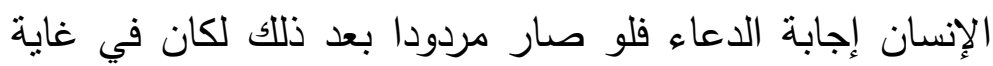

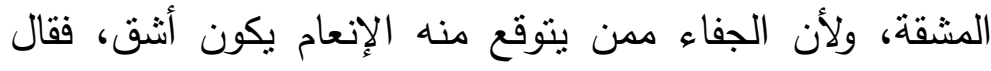

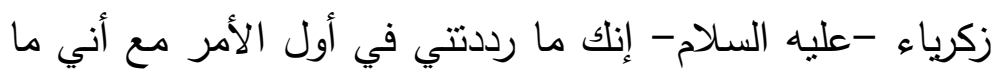

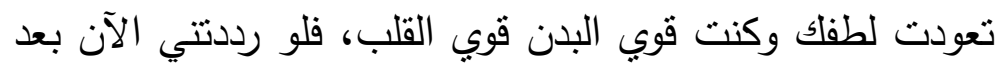

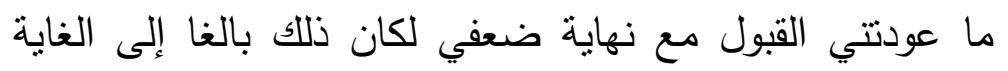

$$
\text { (1)مفاتيح الغيب (21/ 509) }
$$

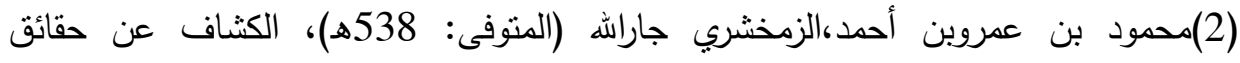

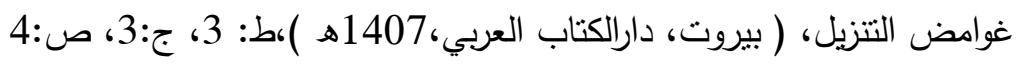




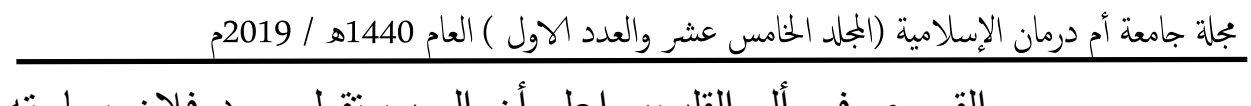

القصوى في ألم القلب، واعلم أن العرب تقول سعد فلان بحاجته إذا ظفر بها وشقي بها إذا خاب ولم ينلها ومعنى بدعائك أي بدعائي إيالك فإن الفعل قد يضاف إلى الفاعل تارة وإلى المفعول

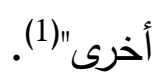

ابن عاشور:

> ذكر مناسبة مشابهة لما ذكرها الرازي في قوله تعالى:

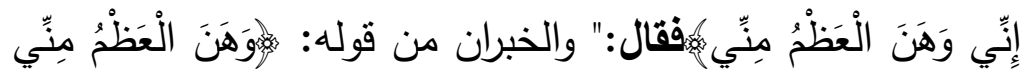

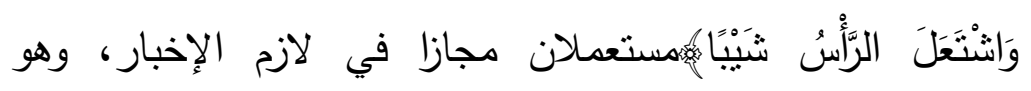
الاسترحام لحاله. لأن المُخبَرعالم بما تضمنه الخبران.والوهن: الضعف. وإسناده إلى العظم دون غيره مما شمله الوهن في جسده لأنهوجز في الدلالة على عموم الوهن جميع بدنه، لأن العظم هو قوام البدن وهوأصلبشيء فيه فلا ييلغه الوهن إلا وقد بلغ ما

$$
\text { فوقه" (2) }
$$

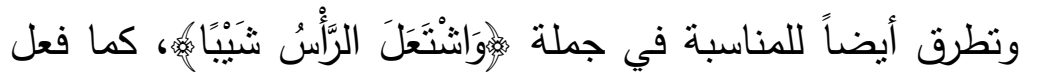
الرازي ناقلاً عن الزمخشري في كثافه، فقال(ابن عاشور):" وشبه عموم الثيب شعر رأسه أو غلبته عليه باشتعال النار في الفحم بجامع انتشار شيء لامع في جسم أسود، وأسند الاشتعال إلى بلى لأس الرأس، وهو مكان الشعر الذي عمه الثيب". > ثم ذكر مناسبة الإتيان بتخصيص شيب الثعر بالذكر ، فقال: " لأن

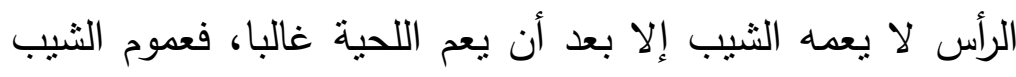
في الرأس أمارة التوغل في كبر السن". > وذكر أيضاً مناسبة في مجئ الثيب تمييزاً، مع تتكيره، فقال:"فلما 
جيء باسم الثيب تمييزا لنسبة الاثتعال حصل بذلك خصوصية

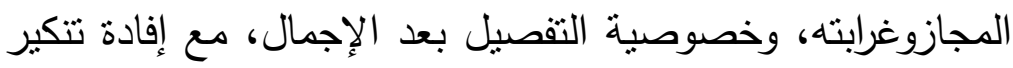

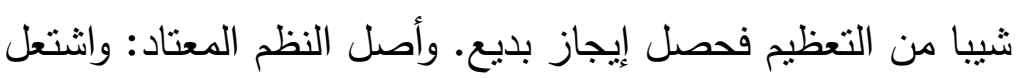
الثيب في شعر الرأس"(1).

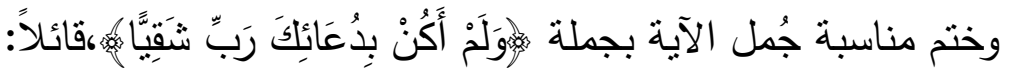

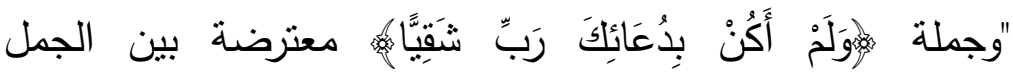
التمريديةوالباء في قوله:بدعائك للمصاحبة"(2) وذكر كلاماً طويلاً

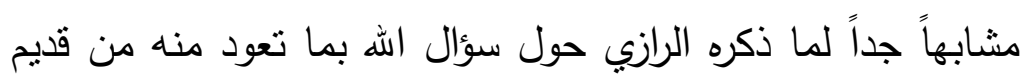

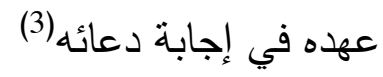

ولعل الإتيان بالباء كما أسلف ابن عاثشور أفاد المصاحبة، يضاف

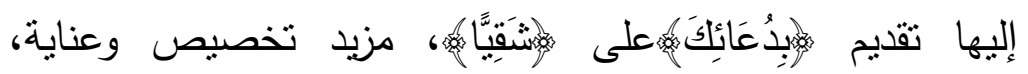

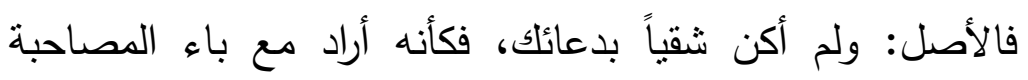

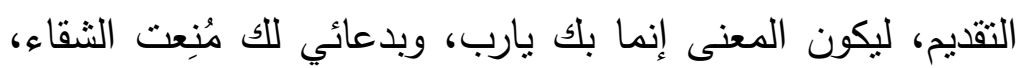

$$
\text { وكانت لي استجابة الدعاء. }
$$

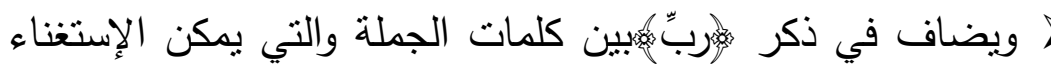

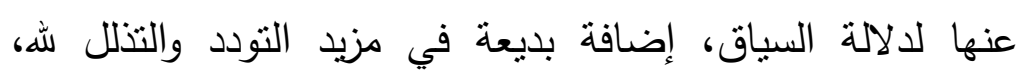

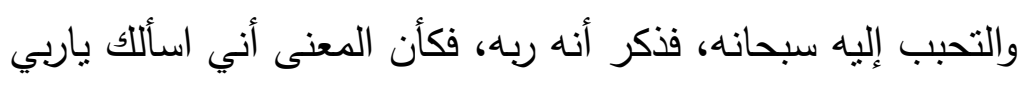

$$
\text { فإذا لم تعطني وأنت الرب،فمن يعطني! }
$$

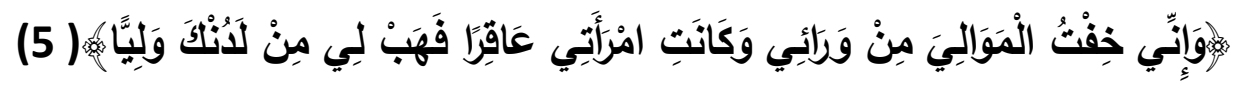
مناسبة الآية لما قبلها:

$$
\text { (1)التحرير والتتوير ، (16/ 64) }
$$

(2):قصد - تمهيده لسؤال الولد، وهي جمل الآية الرابعة، والآية الخامسة، ليسأل بعدها الهـ الولد، بعد أن عرض لله ضعفه الظاهر والباطن وسبب حاجته الدينية للولد. (3)انظر : التحرير والتتوير ، (65/16) 
مجلة جامعة أم درمان الإسلامية (المجلد الخامس عشر والعدد الاول ) العام 1440هـ / 2019م

الرازي:

> ذكر الرازي فيها مناسبة، بأنها نتمة لما قدمه عليه السلام من أسباب الإجابة قبل طلبه الولد، فقال:"واعلم أن زكرياء عليه السلام قدم على الى اله السؤال أمورا ثلاثة: أحدها: كونه ضعيفا. والثاني: أن اله تعالى ما رد دعاءه البتة.والثالث: كون المطلوب بالدعاء سببا للمنفعة في الدين ثم بعد تقرير هذه الأمور الثناثة صرح بالسؤال"(1) ابن عاشور: > لم يذكر هنا أي مناسبة للآية مع ماقبلها، بل انشغل في تفسيرها منوسعاً. المناسبة بين جمل الآية الواحدة: الرازي:

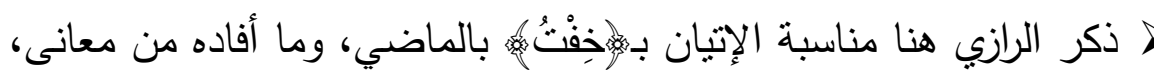
فقال:"ففي الإخبار عنه بلفظ الماضي إعلام بتقادم العهد في ذلك وغرض زكرياء من هذا الكلام بيان استبعاد حصول الولد فكان إيراده بلفظ الماضي أقوى وإلى هذا يرجع الأمر في قوله: "وإني خفت الموالي من ورائي لأنه إنما قصد به الإخبار وعن ثقادم الخوف ثم استغنى بدلالة الحال وما يوجب مسألة الوارث وإظهار الحاجة عن الإخبار بوجود الخوف في الحال وأيضا فقد يوضع الماضي مكان المستقبل وبالعكس قال الله تعالى: 116] والهه أعلم" (2).

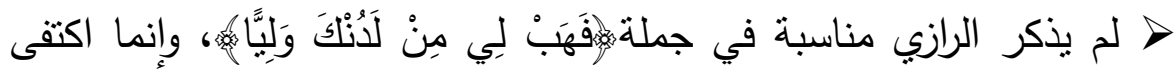
بذكر ماتضمنته من معاني لغوية فقط، واستفاض في ذكر الأقوال التي

$$
\text { فسرت بها. }
$$

(1) مفاتيح الغيب، (508/21)

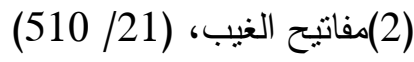


ولعل في قوله خولولياً بأن يكون له ولداً يتولى أمره ويعينه على شأنه

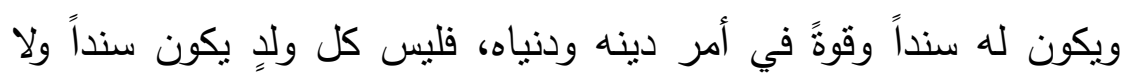
موالياً لوالده، فذالك ولد نوحِ لم يوالي والده في نبوته، وذللك إبراهيم لم يوالي والده بكفره، فسأله - عليه السلام - الولد بعبارة الولي ليجمع بين الحسنيين، ولد لطبيعته البشرية، ووليُّ لصفته النبوية.

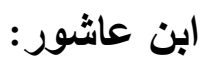

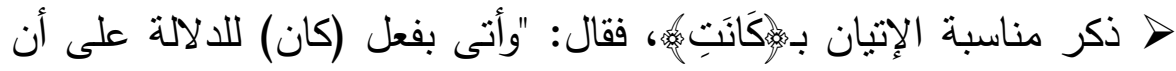
العقر متمكن منها وثابت لها فلذلك حرم من الولد منها" (1).

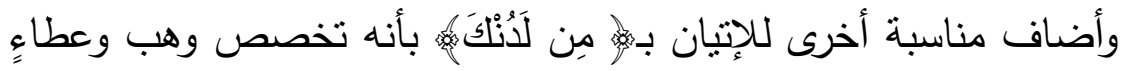

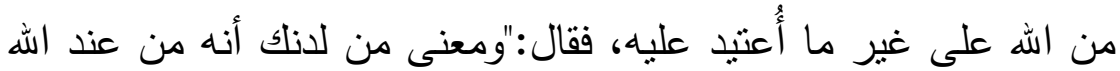

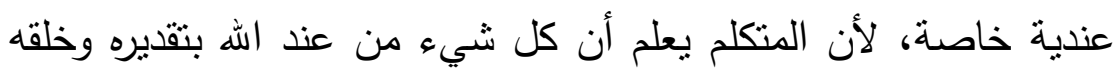

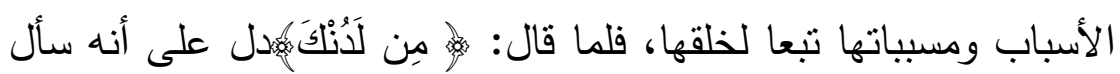

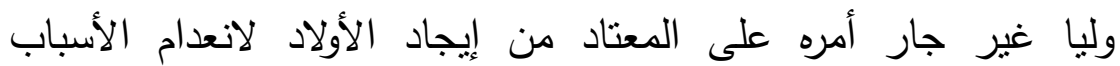
المعتادة، فتكون هبته كرامة له" (2).

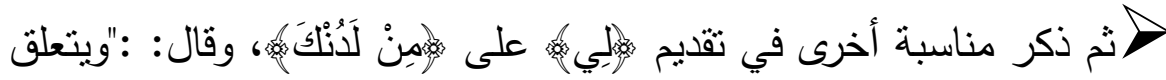

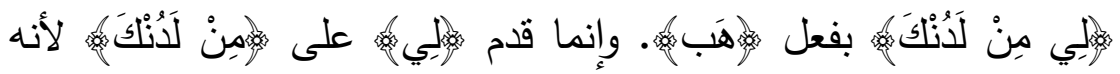

الأهم في غرض الداعي، وهو غرض خاص يقدم على الغرض العام"(3).

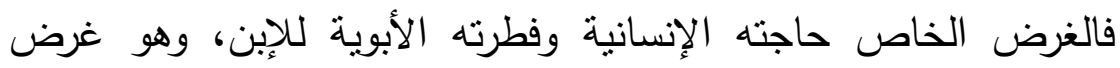

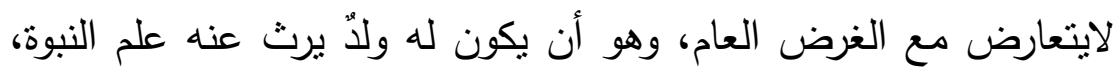

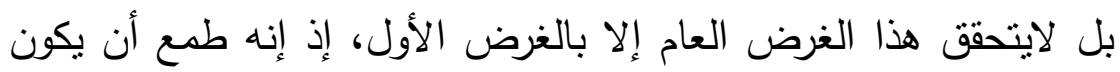

$$
\begin{aligned}
& \text { (1) التحرير والتتوير ، (16/ 67) } \\
& \text { (2) النحرير والتتوير ، (16/ (67) ، (67) (16) } \\
& \text { (3) التحرير والتتوير ، (16/ 67) (67) (67) }
\end{aligned}
$$




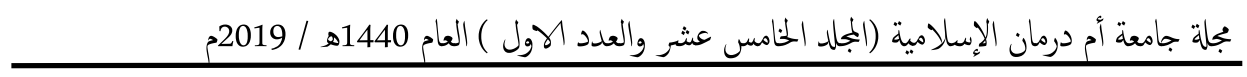

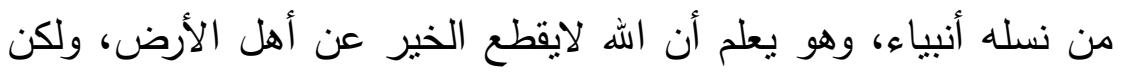

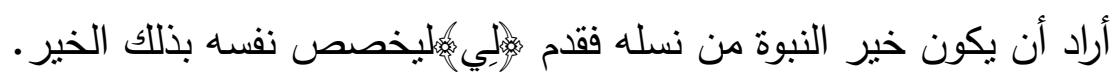

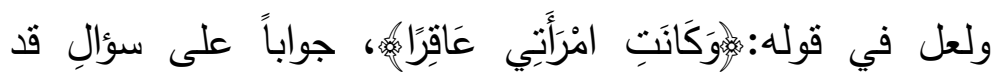

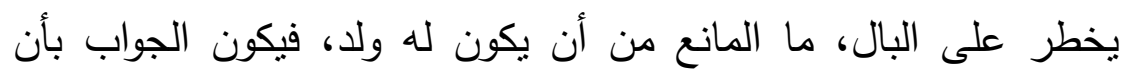

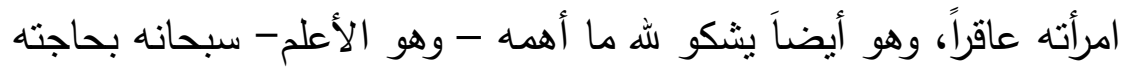
وبما أهمه، ولكنه سبحانه يحب أن يسمع صوته مناجاة عبده، وما يعيقه لهانه عن بلوغ مراده.

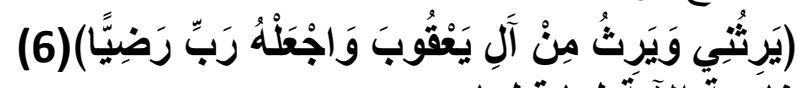

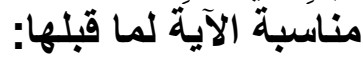

> لم يذكر لذلك مناسبة، وإنما توسع بتفسير الورث وما ذكر فيه من أقوال،

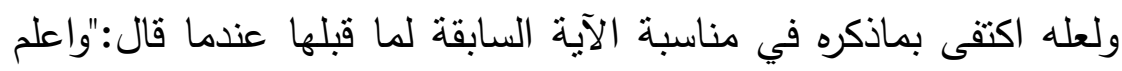
أن زكرياء عليه السلام قدم على السؤال أمورا ثلاثة: أحدها: كونه ضعيفا.

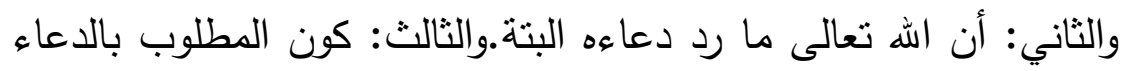

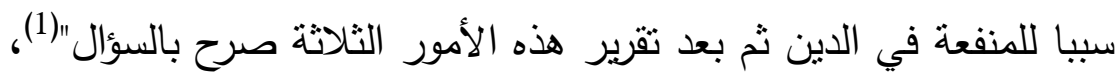
فبقوله تكون هذه الآية تتمة للآية السابقة في إثبات أنماطلبه سبيا للمنفعة في الدين، وخدمة له. (بن عاشور

لم يذكر مناسبة للآية مع ما قبلها ولكن يمكن استخلاصها من ذكره

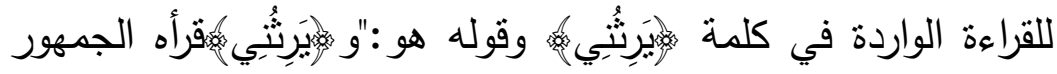

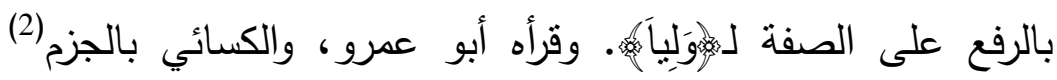

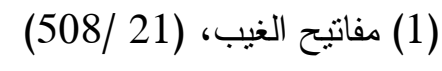

(2) ينظر : القاضي، عبد الفتاح بن عبد الغني بن محمد القاضي (المتوفى: 1403هـ)، البدور

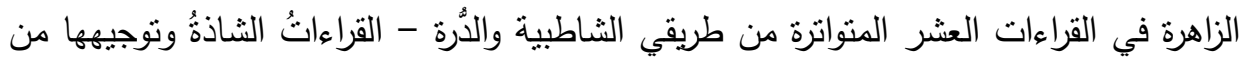

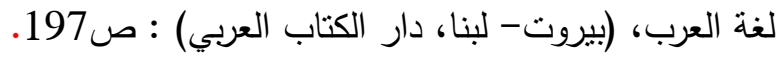




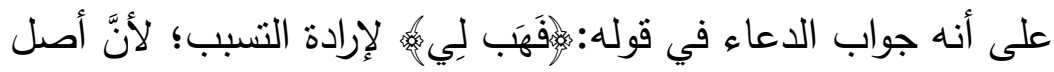

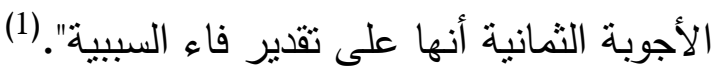

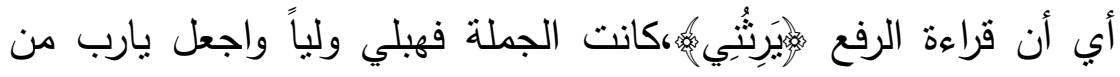

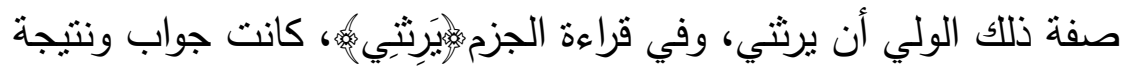
الدعاء، أي ادعو الله تعالي بالولد فيولد، فينتج عن ولادته أن يكون وريثاً

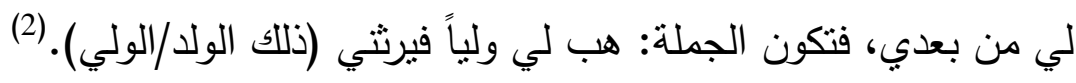

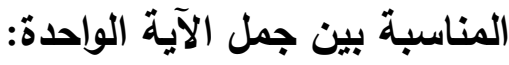

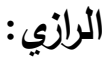

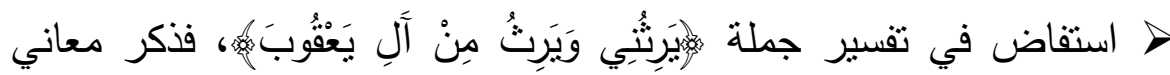

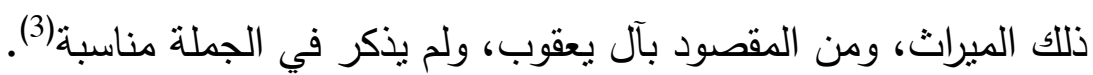

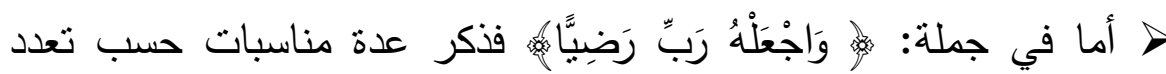
معانيها، كلها تذور على تخصص ذلك الولد بمزيد عناية من اله له، فقال: "واعلم أنهم ذكروا في تفسير الرضي وجوها. أحدها: أن المراد

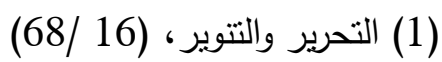

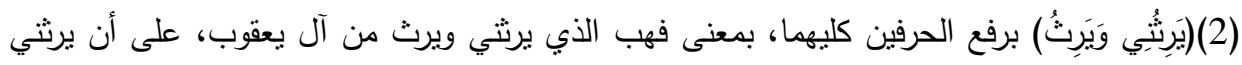

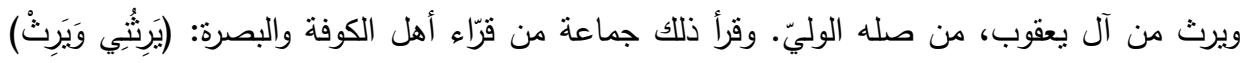

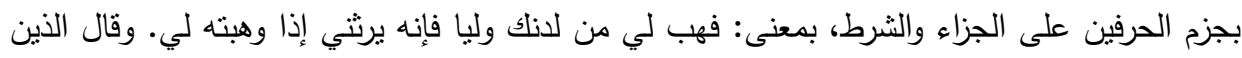

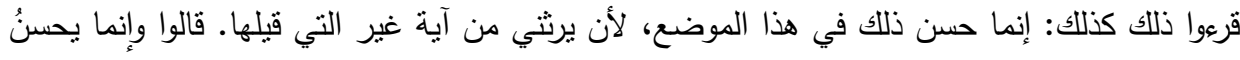

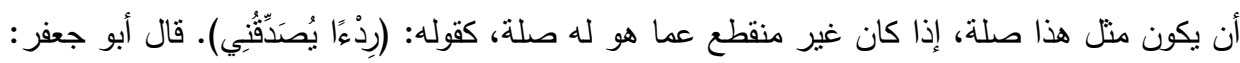

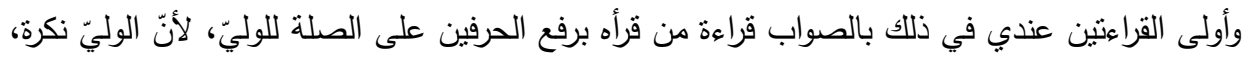

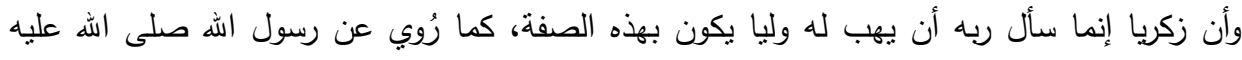

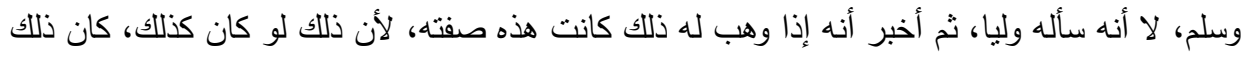

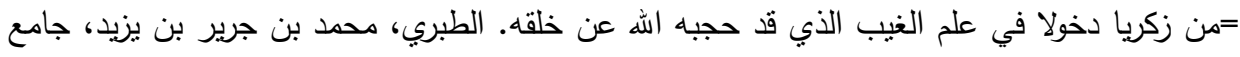

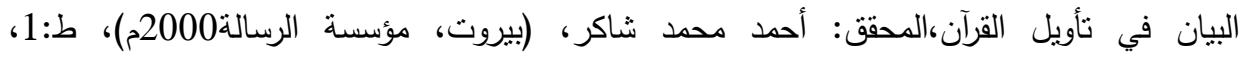

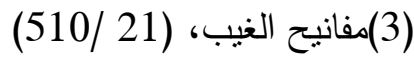




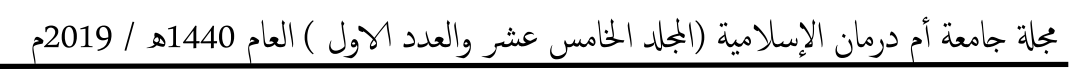

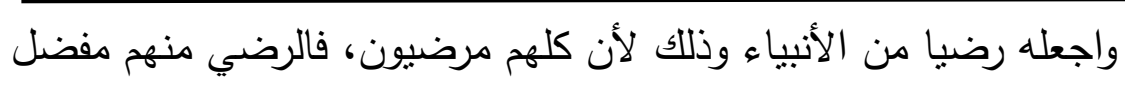

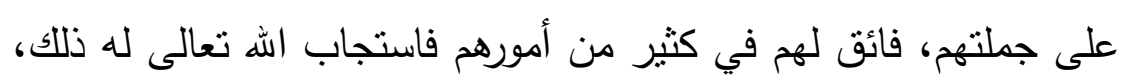

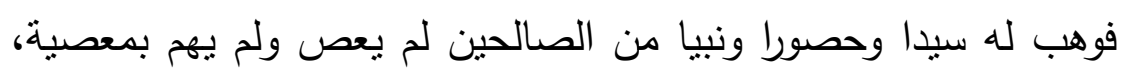

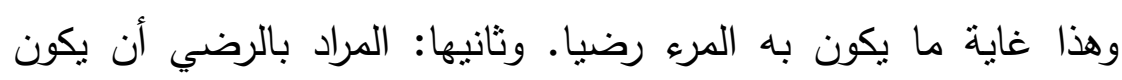

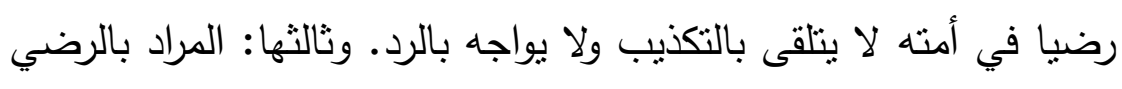

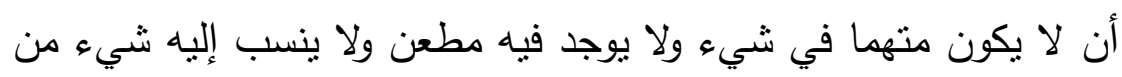

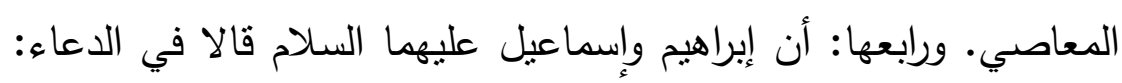

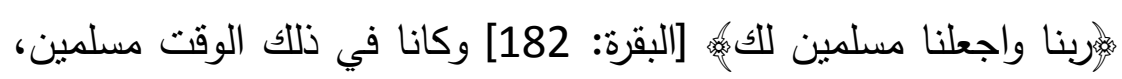

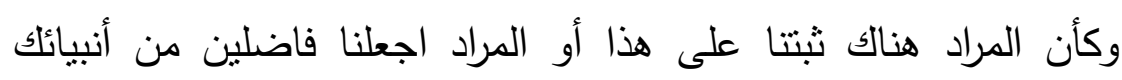

$$
\text { المسلمين فكذا هاهنا"(1). }
$$

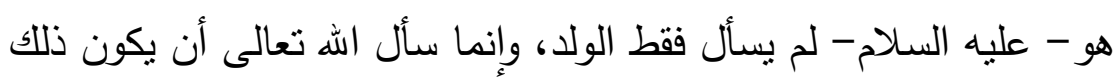

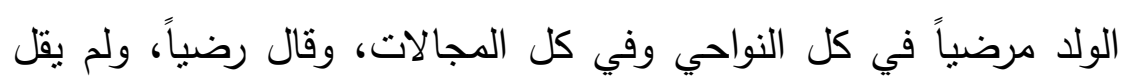

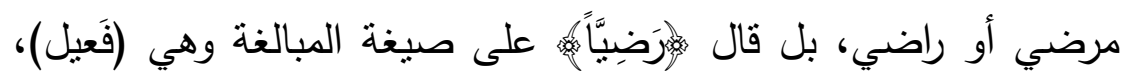
ليفيد مزيداً من التوكيد على صلاح وانصلاح ذلك الموهوب منه سبحانه، ليكون فعلاً ولياً بكل معاني الولي. لئركي. ابن عاشور:

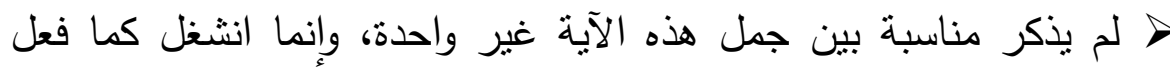

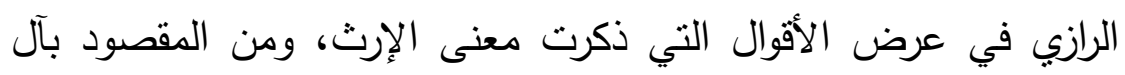

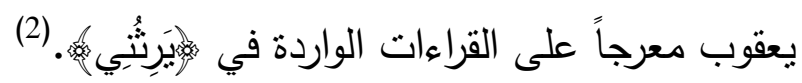

$$
\text { (1) مفانيح الغيب ، (21) (511) }
$$

(2)(انظر : التحرير والتتوير ، (16/ (68) 
الخاتمة:

من خلا التعرف على علم المناسبات بأقسامه، والتعريف بهذين الإمامين،

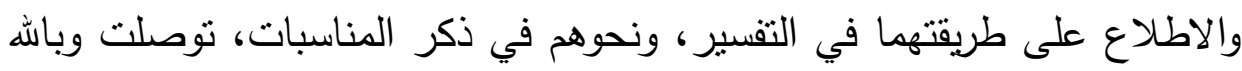

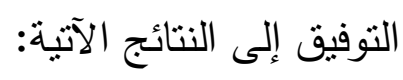

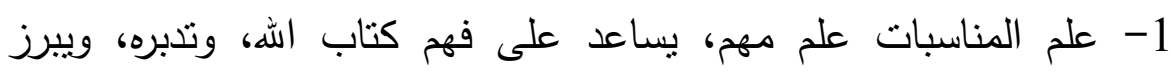
الإعجاز البلاغي في اختيار كل كلمة فيه دون غيرها.

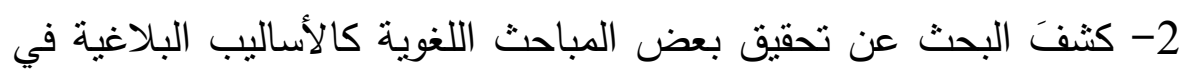

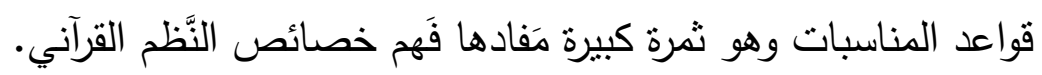
3- إثراء مخزون علم المناسبات على يدي العالمين الجليلين، أثنابهم الله الجنة. 4- كثيراً ما يتفق العَالمِين في ذكر المناسبة، وإن اختلفا، فاختلافهما، اختلاف تتوع، لاتضاد، كأنَّ أحدهما يكمل الآخر.

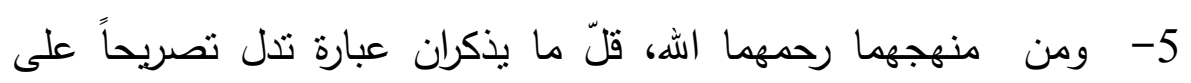
المناسبة، بل قد يذكران عبارة (تعلق)، وعبارة (لما)، فسيندل القارئ من خلاد السياق إلى أنها مناسبة. 6- لايذكر الرازي ولا ابن عاشور مناسبة السورة لما قبلها، ولا مابعدها.

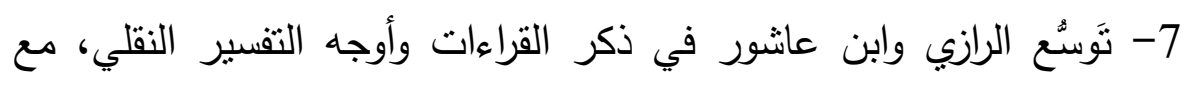
ماذكروه من التفسير الاجتهادي الذي تتضمنه المناسبات، فجمعا الحسنيين. 8- يكثز الرازي رحمه الله النقل عن صاحب الكثاف (الزمخشري) في المناسبات وغيرها. 
مجلة جامعة أم درمان الإسلامية (المجلد الخامس عشر والعدد الاول ) العام 1440هـ / 2019م

فهرس المصادر والمراجع

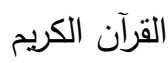

* ابن أبي أصيبعة، أحمد بن القاسم بن خليفة بن يونس، عيون الأنباء في طبقاتالأطباء،

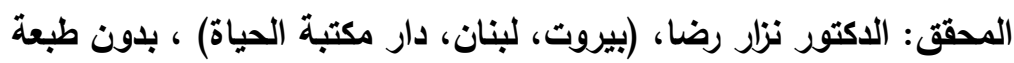

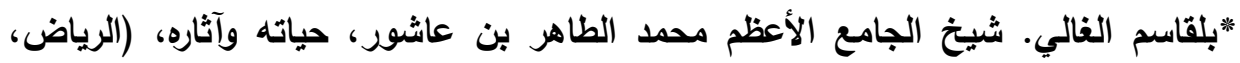

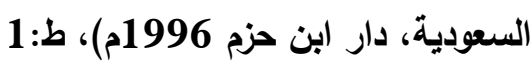

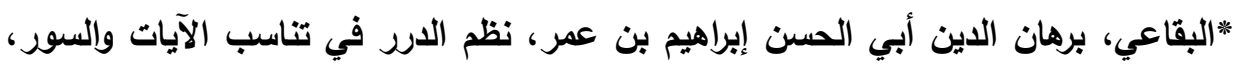

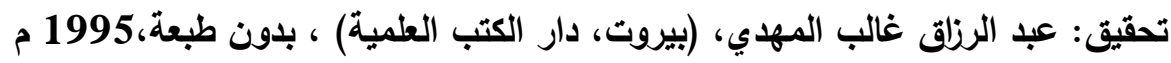

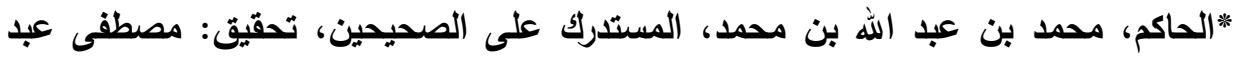

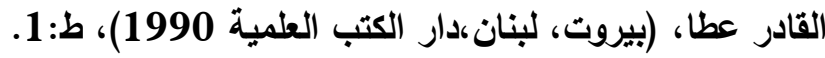

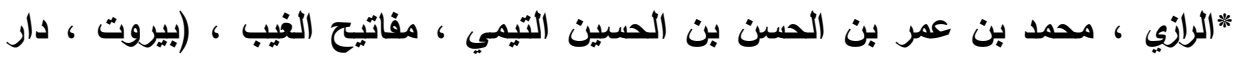

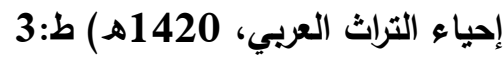
* الزركلي، خير الاين بن محمود بن محمد بن علي، الأعلام (بيروت،لبنان، دار العلم

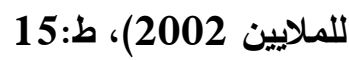
* الزخخشري، جار الله محمود بن عمرو بن أحمد، (المتوفى: 538هـ) ، الكثاف عن حقائق

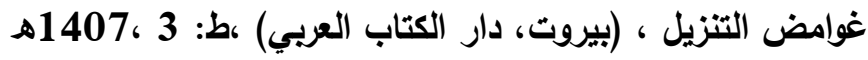
"السبكي، تاج الدين عبد الوهاب بن تقي الدين ، طبقات الثافعية الكبرى، تحقيق: محمود

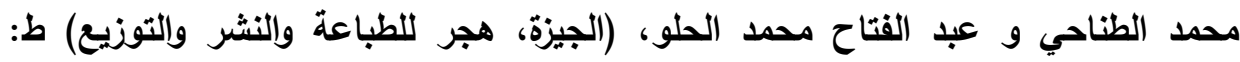

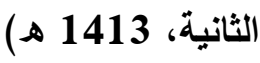

"الطبري، محمد بن جرير بن يزيد، جامع البيان في تأويل القرآن،المحقى: أحمد محمد شاكر،

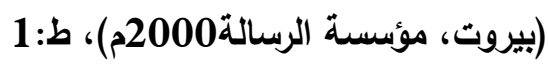
*عادل نويهض، معجم المفسرين من صدر الإسلاموحتى العصر الحاضر، تحقيق: حسن طن

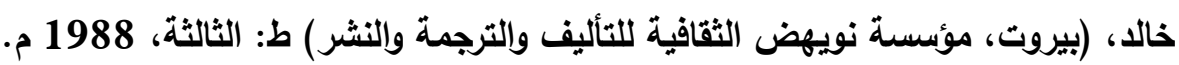
*ابن عاشور، محمد الطاهر بن محمد بن محمد، التحرير والتتوير، (تونس، الدار التونسية التهية

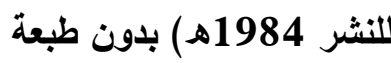
*ابن فارس، أحمد بن فارس بن زكريا (المتوفي1004هـ)، معجم مقاييس اللغة، المحقى:

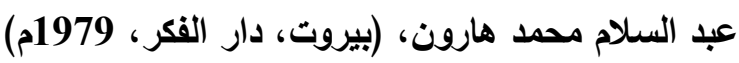


"القاضي، عبد الفتاح بن عبد الغتي بن محمد القاضي (المتوفى: 1403هـ)، البدور الزاهزة

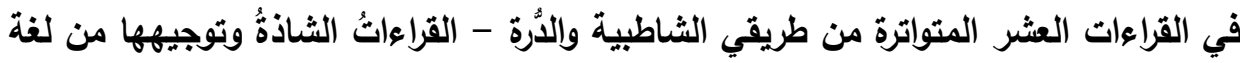
العرب، (بيروت - لبنا، دار الكتاب العربي). *القفطي، جمال الدين أبو الحسن علي بن يوسف بن إبراهيم الثيباني (المتوفى: 646 هـ)،

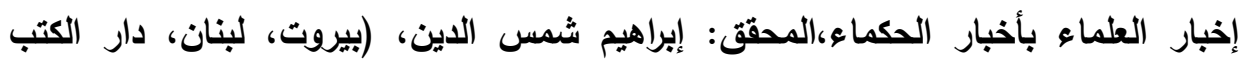

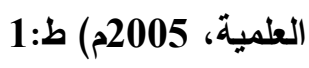

* ابن كثير، إسماعيل بن عمر، طبقات الثافعيين، تحقيق:أحمد عمر هاشم، محمد زينهر

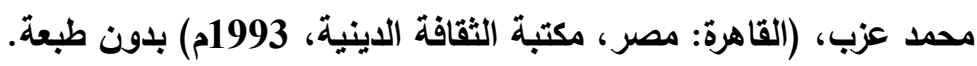

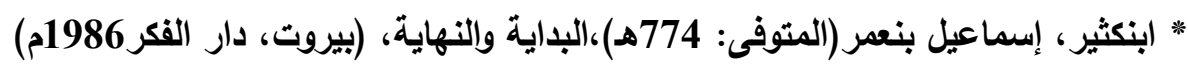
*المعالم الجغرافية القليمبرستان، مجلة كلية التربية الأساسية، جامعة بابل، 2013، العدد10

*محد بن عمر بن سالم بازمول، علم المناسبات في السور والآيات، (مكتبة مكة،

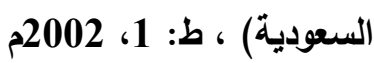

"محمد محفوظ. تراجم المؤلفين التونسين، (بيروت،دار الغرب الإسلامي 1982) ط: ط: 1)

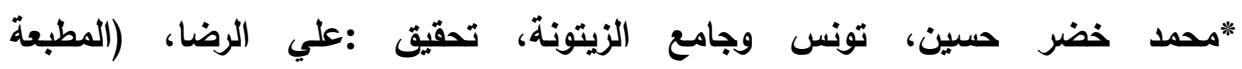

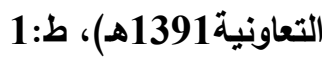
*ياقوت بن عبد الله الحموي ، معجم البلدان، (بيروت، دار الصادر، 1995م) ، ط:1 